\title{
MAE-GC-MS Assessment of Polyaromatic Hydrocarbons in the Bitumen Belt of Ondo State, Southwestern Nigeria
}

\author{
Tomori W. B. ${ }^{1,2}$, Yanful E. K. ${ }^{1}$, Amoo I. A. ${ }^{2}$, Aiyesanmi A. F. ${ }^{2}$ \\ ${ }^{1}$ Department of Civil and Environmental Engineering, Western University, London, Ontario, Canada \\ ${ }^{2}$ Department of Chemistry, The Federal University of Technology, Akure, Nigeria
}

Email address:

wbtomori@futa.edu.ng (Tomori W. B.), wtomori@uwo.ca (Tomori W. B.), eyanful@uwo.ca (Yanful E. K.), adisamoo@yahoo.co.uk (Amoo I. A.), demolaktp@yahoo.co.uk (Aiyesanmi A. F.)

To cite this article:

Tomori W. B., Yanful E. K., Amoo I. A., Aiyesanmi A. F. MAE-GC-MS Assessment of Polyaromatic Hydrocarbons in the Bitumen Belt of Ondo State, Southwestern Nigeria. International Journal of Environmental Monitoring and Analysis. Vol. 5, No. 2, 2017, pp. 41-47. doi: 10.11648/j.ijema.20170502.14

Received: October 4, 2016; Accepted: December 26, 2016; Published: March 25, 2017

\begin{abstract}
Polyaromatic hydrocarbons (PAHs) are of particular concern because of their mutagenic and carcinogenic effect on diverse ecosystems. The regional PAHs concentration was determined in soil over the bitumen belt of Ondo state, Southwestern Nigeria using MAE-GC-MS technique. The spatial concentrations of PAHs in the study area did not show any appreciable variation in all the soil samples analysed most especially surface soil. The surface soil shows that PAHs are derived principally from pyrogenic origin typically bush burning while subsurface soil PAHs origins were both pyrogenic and petrogenic. Though, the distributions of PAHs in the study area were not of any public concern because their concentrations were lower than quoted contaminated averages, however, the petrogenic origin in some part of study area may arose from surface oozing of bitumen and thus a concern for crop production in the affected areas.
\end{abstract}

Keywords: Soil, Regional, Concentration, PAHs, Bitumen

\section{Introduction}

Polyaromatic hydrocarbons (PAHs) are organic compounds with two (e.g. naphthalene) or several (e.g. benzo (a) pyrene) fused rings $[1,2]$. They are of particular concern because of their mutagenic and carcinogenic properties [3, 4]. In the first place, this raises issues about human health risks $[4,5]$, because they are converted into products that can interact with Deoxyribonucleic acid (DNA) causing untold health hazards (1). Environmental contamination is by complex of PAHs and not by single compound [6]. Processes that introduce PAHs into the environment take place almost everywhere in the ecological system [7]. Polycyclic aromatic hydrocarbons released into the atmosphere have a strong affinity for airborne organic particles and can be moved great distances by air currents. The molecules are eventually transported to earth as wet or dry particulate deposition [8].

Polyaromatic hydrocarbons are found in air, water, sediment and soil; and through these they enter into food web $[5,9]$. They can be bioconcentrated or bioaccumulated by organisms that lack capacity for effective biotransformation
[10]. Mammals' especially human being occupies the highest level in the food chain; the observed toxicity, mutagenesis and carcinogenicity become an important health issue for consideration in respect of the concentration of PAHs in the environment especially soil. To determine soil concentration of PAHs is therefore an important source of information. Sample preparation and analytical techniques used in the determination of PAHs in soil are diverse [6, 7, 11-13] and the concentrations of PAHs observed in environmental media in Nigeria are varied [14-22].

The present study area is part of the Nigeria bitumen belt that extends from Lagos state through Ogun, Ondo and terminates in Edo State (Figure 1). Presently in Ondo State bitumen belt, there has not been any significant exploitation other than occasional outcrops and seepages of the bitumen oil in area where deposits were close to the surfaces. There is paucity of information on regional concentrations of PAHs in the belt; the presently available knowledge is site specific. There have been recent demarcations of the belts into blocs for investors for possible commencement of bitumen exploitation. This study therefore attempts to examine the regional concentration of PAHs in the surface and subsurface 
soil samples in the whole bitumen belt with a view to report perhaps for the first time the regional concentrations of PAHs

across the belt prior to bitumen exploitation.

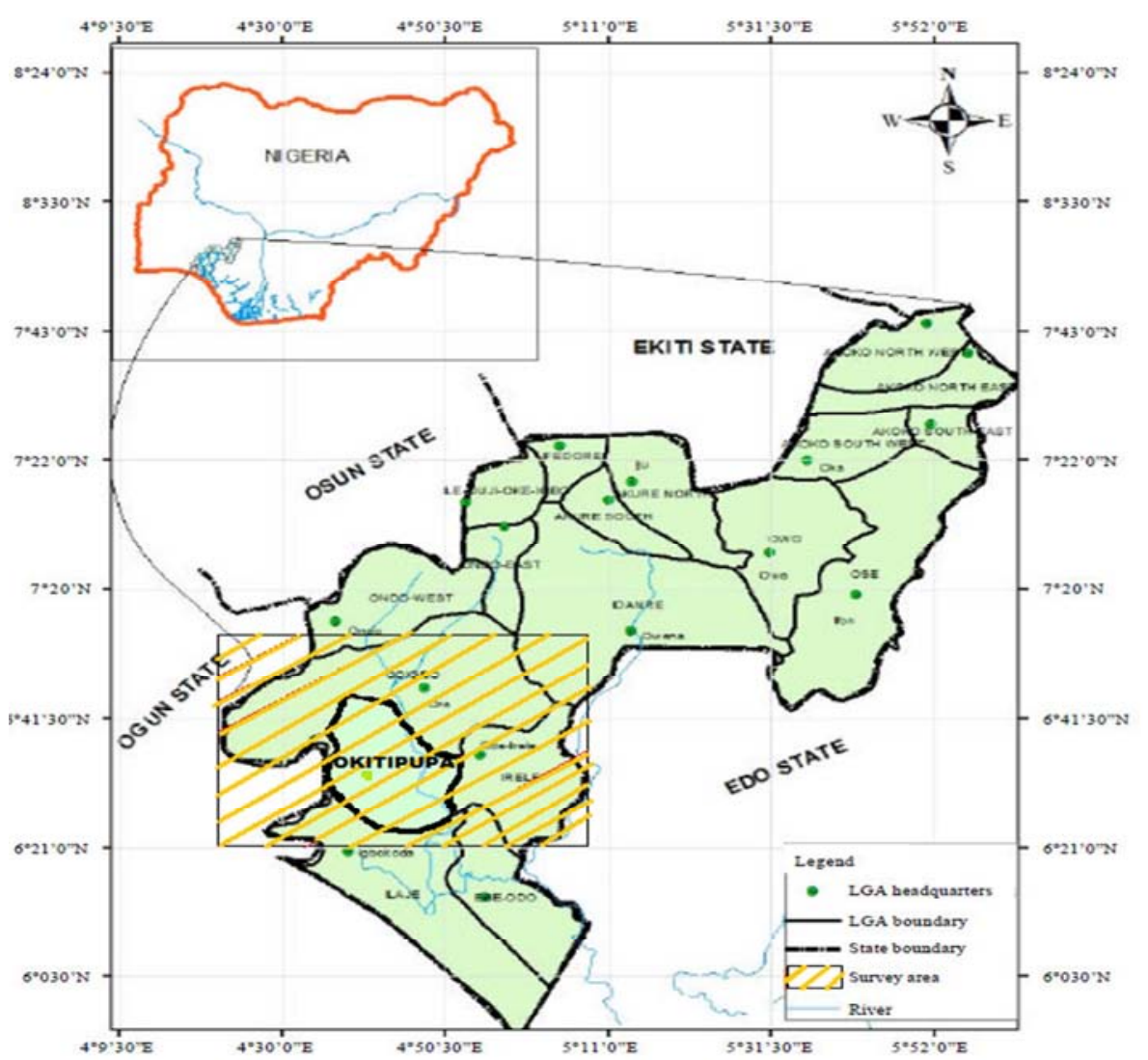

Figure 1. Map Showing the Study Area.

\section{Experimental}

\subsection{Microwave-Assisted Extraction of PAHs}

A CEM MARS Xpress Microwave Accelerated Reaction System (CEM Corporation, Matthews, NC, USA) was used. This system allowed up to 40 extraction vessels to be irradiated simultaneously. In this study, portions of $2.00 \mathrm{~g}$ soil was weighed into $55 \mathrm{ml}$ perfluoroalkoxy (PFA) polymer extraction vessels equipped with Teflon-sealed lip-tight caps and polyetheretherketone (PEEK)-liners. Microwave power was $1600 \mathrm{~W}(100 \%)$. The extraction solvent was $25 \mathrm{ml} \mathrm{n}$ hexane and acetone $(4: 1, \mathrm{v} / \mathrm{v})$. The extraction was performed in temperature-controlled mode. The extraction temperature was $110^{\circ} \mathrm{C}$ and programmed as follows: ramp to $110^{\circ} \mathrm{C}$ for $10 \mathrm{~min}$, holding at $110^{\circ} \mathrm{C}$ for $15 \mathrm{~min}$. After the extraction completed, soil and solvent were separated by filtration into a pear-shaped flask [23].

\subsection{Sample Concentration for PAHs}

The extracts was transferred to $100-\mathrm{mL}$ pear-shaped flasks and evaporated to nearly dryness under reduced pressure of 150 mbar at $35^{\circ} \mathrm{C}$ using a rotary evaporator (Buchi Switzerland Rotavapor R-210 fitted with thermostated heating bath B-491 and vacuum controller V-850). An additional $10 \mathrm{ml} \mathrm{n}$-hexane was added to the concentrated extracts and evaporated to a small volume (about $1 \mathrm{ml}$ ). Then the sample was transferred to $1.5 \mathrm{ml}$ chromatographic vial for gas chromatography analysis [16].

\subsection{Sample Analysis for PAHs}

The PAHs were quantified by internal calibration performed with a GC/MS (Agilent GC6890/5973MSD). For PAHs analysis, a HP-5 MS column (Aglient, length 30 m, i.d. $0.25 \mathrm{~mm}$, film thickness $0.25 \mathrm{~mm}$ ) was employed with the following temperature program: $60-280^{\circ} \mathrm{C}$ at $6^{\circ} \mathrm{C}$ min-1, isothermal holding at $280^{\circ} \mathrm{C}$ for $20 \mathrm{~min}$ using helium as the carrier gas. The instrument was operated with an initial flow of $1.2 \mathrm{~mL} \mathrm{min-1,} \mathrm{head} \mathrm{pressure} 0.03 \mathrm{Mpa}$, and injection mode as follows: splitless $(1 \mathrm{~mL})$, temperature of injector: $280^{\circ} \mathrm{C}$. The MS was operated using the electron impact (EI) ionization mode at $70 \mathrm{Ev}$, scanning from 50 to 550 mass units at $0.82 \mathrm{~s}$ scan-1. All PAHs were determined by selective ion monitoring (SIM) [24].

\section{Results and Discussion}

\subsection{Regional Concentration Patterns of PAHs}

All PAHs were identified and determined in all soil samples (Tables 1-2); the spatial concentration of PAHs in 
the study area did not show any appreciable variation as most data obtained were almost constant for all the PAHs in all the soil samples analysed. This is especially true for surface soil samples (Figures 2-3). The relative individual dominance of PAHs in surface soil were in the order dibenzo $(\mathrm{a}, \mathrm{h})$ perylene $>$ benzo (b) fluoranthene $=$ benzo $(g, h, i)$ perylene (Figure 2) while the subsurface samples show two different patterns namely dibenzo (a, h) anthracene>benzo (b) fluoranthene $=$ chrysene $>$ benzo $(\mathrm{g}, \mathrm{h}, \mathrm{i})$ perylene $=$ indeno $(1,2,3$, cd) pyrene; and then acenaphthene $>$ fluorine $>$ phenanthrene (Figure 3 ). The surface soil samples shows that 2-3, 4- and 5-rings PAHs are equally dominant in all the sample analysed (Figure 2) while in the subsurface soil samples, two patterns were observed. The first pattern follow a similar trend with surface samples with 2-3, 4- and 5- rings PAHs showing equal dominancy while in the second pattern 2-3 rings PAHs are the dominant PAHs having 60\% contribution to total concentration of PAHs (Figure 3). The total PAHs ( $\Sigma$ PAHt) values of the surface soil samples ranged from $1.99 \mathrm{mg} / \mathrm{kg}$ to $2.06 \mathrm{mg} / \mathrm{kg}$ with a mean value of 2.02 $\mathrm{mg} / \mathrm{kg}$ (Table 1); while that of the subsurface soil samples ranged from $1.52 \mathrm{mg} / \mathrm{kg}$ to $1.56 \mathrm{mg} / \mathrm{kg}$ with a mean value of $1.53 \mathrm{mg} / \mathrm{kg}$ (Table 2). The concentration of total PAHs in all samples analysed are less than $250 \mathrm{ng} / \mathrm{g}$ (which represent contamination) (25), hence the area under study are free from PAHs contamination. Olajire et al (2007) [17] had earlier reported values of $\Sigma$ PAHt in soil samples taken from the vicinity of Agbabu bitumen field to be in the range 101.6 to 180.6 (ng/g DW). For surface soil samples the organic carbon normalized PAHs (PAHs/OC) concentration ranged from 0.8896 to 1.2679 with an average of 1.0446 . The majority of samples have values above one (Table 1); while for subsurface samples it ranges from 1.278 to 3.676 with mean value of 1.0816 (Table 2); all values are above one. The total concentration of potentially carcinogenic PAHs which includes benzo (a) anthracene, benzo (b) fluoranthene, benzo (a) pyrene, indeno $(1,2,3$, cd) pyrene and dibenzo $(\mathrm{a}, \mathrm{h})$ anthracene varied from 0.81 to 0.83 with an average value of 0.82 for surface samples (Table 1) while this is constant all through the analysed samples for subsurface samples at a value of 0.82 (Table 2). All these quoted values did not indicate contamination of PAHs in the study area.

\subsection{Diagnostics Sources of PAHs}

A number of parent and alkyl PAHs have been used to interpret PAHs sources in the environment [26]. In order to characterize PAHs with respect to sources, a number of diagnostics ratio are conventionally in use $[1,15,21,22,26-$ 35]. Flt/Pyr and Phen/Anth [29]; ratio of Flt/Flt+Pyr [30]; Anth/Anth+Phen; $\mathrm{BaA} / \mathrm{BaA}+\mathrm{Chry} ; \mathrm{InP} / \mathrm{InP}+\mathrm{BgP}$ [1]; total index:

Anth/(Anth+Phen $) / 0.1+$ Flt/(Flt+Pyr $) / 0.4+\mathrm{BaA} /(\mathrm{BaA}+\mathrm{Chr}) / 0$. $2+\operatorname{InP} /(\operatorname{InP}+\mathrm{BgP}) / 0.2[1]$. The sources of PAHs in this study were investigated using the following diagnostics parameters. A Flt/Flt+Pyr ratio of $<0.4$ indicates PAHs suggests typical petroleum contamination e.g. crude oil, diesel etc, while Flt/Flt + Pyr $>0.5$ indicates PAHs from combustion of grass, wood and coal and $0.4<$ Flt $/$ Flt + Pyr $<0.5$ from liquid fossil fuel combustion such as vehicular exhaust emission [30]. The Flt/Flt+Pyr ratio in this study is a constant value of 0.5 (Table 1) for surface samples and between 0.48 and 0.54 for subsurface samples (Table 2). It implies that the PAHs are of pyrolytic/combustion origin (i.e. during bush burning activities) for the majority of both surface and subsurface samples with exception of sample 18 for subsurface sample which could results from combustion of liquid fossil fuel during vehicular or boat activities. The ratio $\mathrm{BaA} / \mathrm{BaA}+\mathrm{Chry}$ and $\mathrm{InP} / \mathrm{InP}+\mathrm{BgP}$ of $<0.2$ indicates petroleum inputs while values $>0.35$ and $>0.5$ respectively indicates pyrolytic source $[22,26,31]$ and in-between indicates mixed sources [32]. The values obtained for the first ratio in this study for both surface and surface samples (0.485) indicated that the sources of PAHs are from pyrolytic source $(>0.35)$ while that of the second ratio for both surface and subsurface samples (0.467) indicated a liquid fossil fuel origin. It is equally generally accepted that $\mathrm{Flt} / \mathrm{Pyr}<1$ and $\mathrm{Flt} / \mathrm{Pyr}>1$ are respectively petrogenic and pyrogenic sources. This ratio for the analysed samples show that the source of PAHs is pyrolytic as the values are either 1 or $>1$ except for subsurface sample 18 which is slightly less $(0.923)$. The ratio $\mathrm{Naph} / \mathrm{Phen}$ is used to assume the presence of fresh and unweathered petroleum if it is greater than unity [15, 33]. For the majority of sites this ratio for surface soil samples indicated petrolytic origin as the majority of values are greater than unity; while for subsurface samples, there are two patterns, samples 1 to 12 are generally either slightly less or greater than unity (0.86-1.54) indicating petrogenic origin and samples 13 to 19 are generally lower than unity $(0.31$ 0.39) indicating pyrogenic. Olajire et al (2005) [15] has expressed fear that ambiguity and difficulty usually occur in interpretation of results using more than two criteria and they concluded that the reliability of results of these ratios should be checked by the amount of particular PAHs compounds. They therefore said that the predominance of 2-3 rings PAHs indicates a petrogenic sources and the predominance of 4-6 rings PAHs is related to pyrolytic. This can be expressed in terms of ratio of 2-3 rings/4-6 rings PAHs and that values $>1$ is petrogenic while $<1$ is pyrolytic. It was equally expressed as ratio of low molecular weight $\{\Sigma$ (phenanthrene, anthracene, fluoranthene and pyrene) $\}$ and high molecular weight $\{\Sigma$ (benzo(a)anthracene, chrysene, benzo(a)pyrene, benzo(e)pyrene, benzo(b)fluoranthene, benzo(k)fluoranthene, indeno(1,2,3,cd)pyrene, dibenzo(a,h)anthracene and benzo(g,h,i)perylene) $\}$ based on a combustion matrix of PAH compounds with a cutoff point of 1 between petrogenic $(>1)$ and pyrogenic $(<1)$ by Soclo, et al, (2000) [34]. Based on this study, the values obtained for surface samples were all $<1$ indicating pyrolytic origin while subsurface samples shows pyrolytic PAHs origin for samples 1 to $12 \quad(<1)$ and petrogenic sources for samples 13 to $19(>1)$. Orecchio, (2010) [35] and Zhang, et al (2011) [1] have equally expressed a similar fear to Olajire et al (2005) [15] that as the source of PAHs in a matrix could be different and occasional, they proposed a total index as sum of all ratio normalised for limit (low temperature-high temperature source) to 
characterized the source of PAHs. They considered PAHs originating by high temperature processes (combustion) when the total index was $>4$ while lower values indicated low temperature source (petroleum products). The total index for the investigated surface soil samples is $>4$ (6.00) indicating high temperature source while for subsurface soil samples is slightly $<4$ (3.78-3.92) indicating probably low temperature source (petrogenic).

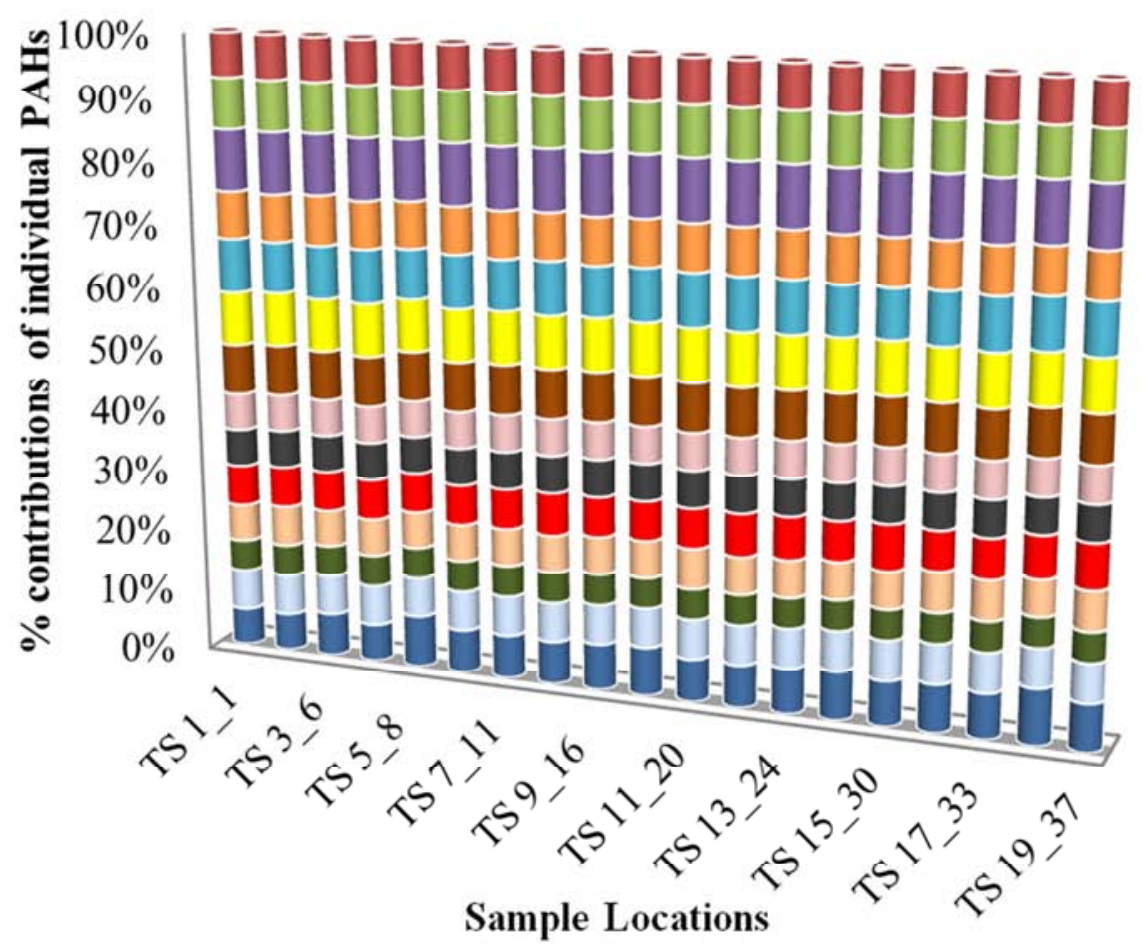

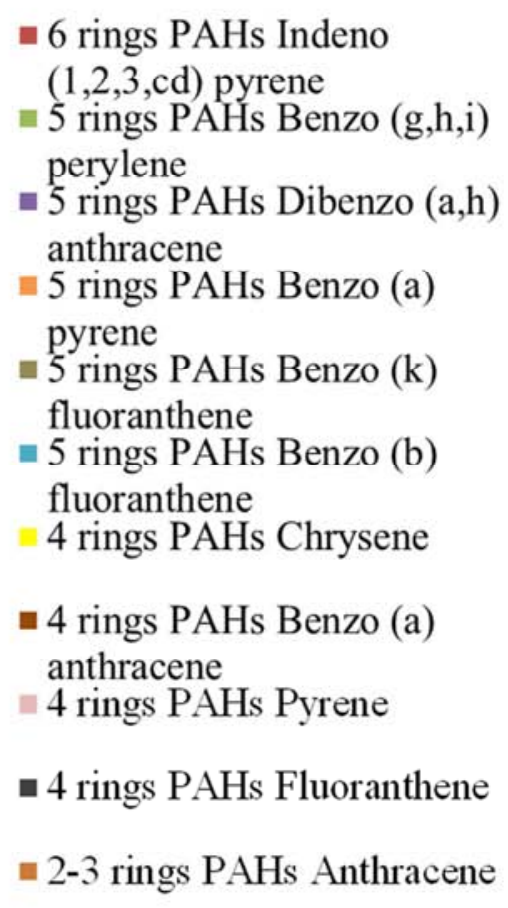

Figure 2. Characteristic Distribution Patterns of various PAHs in Surface Soil Samples.

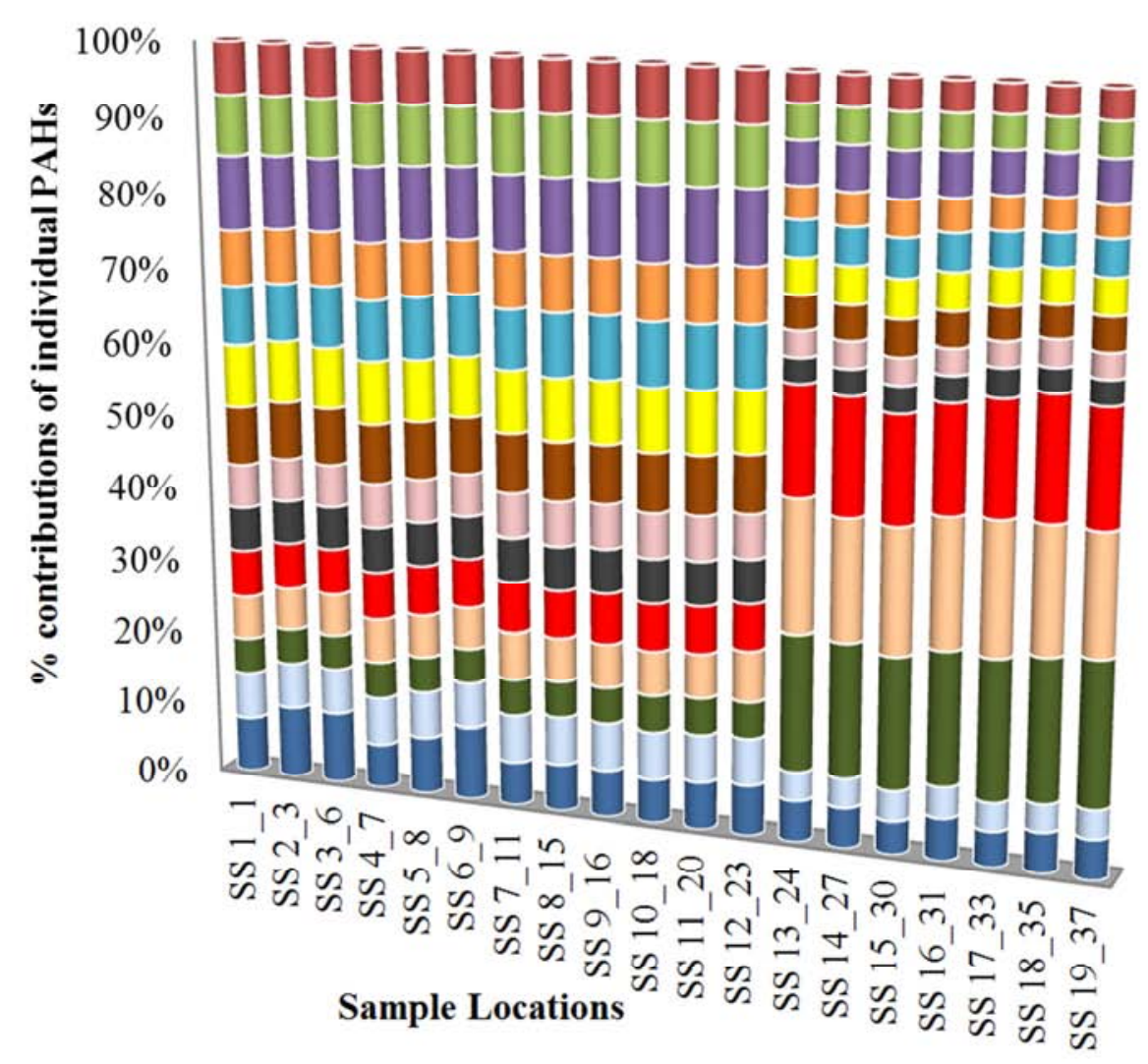

- 6 rings PAHs Indeno $(1,2,3, \mathrm{~cd})$ pyrene $\varpi 5$ rings PAHs Benzo $(\mathrm{g}, \mathrm{h}, \mathrm{i})$ perylene

- 5 rings PAHs Dibenzo $(\mathrm{a}, \mathrm{h})$ anthracene

$=5$ rings PAHs Benzo (a) pyrene

= 5 rings PAHs Benzo $(\mathrm{k})$

fluoranthene

$\square 5$ rings PAHs Benzo (b)

fluoranthene

4 rings PAHs Chrysene

- 4 rings PAHs Benzo (a)

anthracene

4 rings PAHs Pyrene

- 4 rings PAHs Fluoranthene

$=2-3$ rings PAHs Anthracene

- 2-3 rings PAHs Phenanthrene

Figure 3. Chracteristic Distribution Patterns of Various PAHs in Subsurface Soil Samples. 
Table 1. Environmental Index of Polyaromatic Hydrocarbons (PAHS) in the Surface Soil Samples.

\begin{tabular}{|c|c|c|c|c|c|c|c|c|c|c|}
\hline & TS 1_1 & TS 2_3 & TS 3_6 & TS 4_7 & TS 5_8 & TS 6_9 & TS 7_11 & TS 8_15 & TS 9_16 & TS 10_18 \\
\hline इPAHs (2-3 rings) & 0.60 & 0.61 & 0.62 & 0.60 & 0.65 & 0.62 & 0.62 & 0.63 & 0.63 & 0.64 \\
\hline$\Sigma$ PAHs (4 rings) & 0.57 & 0.57 & 0.57 & 0.57 & 0.57 & 0.57 & 0.57 & 0.57 & 0.57 & 0.57 \\
\hline$\Sigma$ PAHs (5 rings) & 0.51 & 0.51 & 0.52 & 0.51 & 0.51 & 0.51 & 0.51 & 0.51 & 0.51 & 0.51 \\
\hline$\Sigma$ PAHs (6 rings) & 0.14 & 0.14 & 0.14 & 0.14 & 0.14 & 0.14 & 0.14 & 0.14 & 0.14 & 0.14 \\
\hline ¿PAHs (4-6 rings) & 1.39 & 1.38 & 1.40 & 1.39 & 1.38 & 1.39 & 1.38 & 1.39 & 1.38 & 1.39 \\
\hline$\Sigma \mathrm{PAHt}$ & 1.99 & 1.99 & 2.02 & 1.99 & 2.03 & 2.01 & 2.00 & 2.02 & 2.01 & 2.03 \\
\hline$\Sigma \mathrm{CPAHs}$ & 0.82 & 0.81 & 0.83 & 0.82 & 0.81 & 0.82 & 0.81 & 0.82 & 0.81 & 0.82 \\
\hline$\%$ Organic carbon & 2.11 & 2.00 & 1.88 & 1.88 & 2.75 & 1.59 & 1.87 & 1.74 & 2.56 & 2.04 \\
\hline$\Sigma \mathrm{PAHt} / \mathrm{OC}$ & 0.95 & 1.00 & 1.07 & 1.06 & 0.74 & 1.27 & 1.07 & 1.16 & 0.78 & 1.00 \\
\hline $\mathrm{Fla} / \mathrm{Fla}+\mathrm{Pyr}$ & 0.50 & 0.50 & 0.50 & 0.50 & 0.50 & 0.50 & 0.50 & 0.50 & 0.50 & 0.50 \\
\hline $\mathrm{BaA} / \mathrm{BaA}+\mathrm{Chrys}$ & 0.48 & 0.48 & 0.48 & 0.48 & 0.48 & 0.48 & 0.48 & 0.48 & 0.48 & 0.48 \\
\hline LMW/HMW & 0.32 & 0.32 & 0.32 & 0.32 & 0.32 & 0.32 & 0.32 & 0.33 & 0.32 & 0.32 \\
\hline Naph/Phen & 0.92 & 0.92 & 1.08 & 0.92 & 1.31 & 1.08 & 1.08 & 1.00 & 1.15 & 1.23 \\
\hline Fla/Pyr & 1.00 & 1.00 & 1.00 & 1.00 & 1.00 & 1.00 & 1.00 & 1.00 & 1.00 & 1.00 \\
\hline IndcdP/IndcdP+BghiP & 0.47 & 0.47 & 0.47 & 0.47 & 0.47 & 0.47 & 0.47 & 0.47 & 0.47 & 0.47 \\
\hline Total Index & 6.01 & 6.01 & 6.01 & 6.01 & 6.01 & 6.01 & 6.01 & 6.01 & 6.01 & 6.01 \\
\hline $\begin{array}{l}\text { Ratio of } \Sigma \text { PAHs (2-3 rings)/ } \Sigma \text { PAHs } \\
\text { (4-6 rings) }\end{array}$ & 0.43 & 0.44 & 0.44 & 0.43 & 0.47 & 0.45 & 0.45 & 0.45 & 0.46 & 0.46 \\
\hline
\end{tabular}

Table 1. Continued.

\begin{tabular}{|c|c|c|c|c|c|c|c|c|c|}
\hline & TS 1120 & TS 12_23 & TS 13_24 & TS 14_27 & TS $15 \_30$ & TS 16_31 & TS $17 \_33$ & TS $18 \_35$ & TS 19_37 \\
\hline$\Sigma$ PAHs (2-3 rings) & 0.63 & 0.63 & 0.64 & 0.64 & 0.65 & 0.65 & 0.64 & 0.68 & 0.67 \\
\hline$\Sigma$ PAHs (4 rings) & 0.57 & 0.57 & 0.57 & 0.57 & 0.57 & 0.57 & 0.57 & 0.57 & 0.57 \\
\hline$\Sigma$ PAHs ( 5 rings) & 0.51 & 0.51 & 0.51 & 0.51 & 0.51 & 0.51 & 0.51 & 0.51 & 0.51 \\
\hline$\Sigma$ PAHs (4-6 rings) & 1.39 & 1.39 & 1.39 & 1.38 & 1.38 & 1.39 & 1.39 & 1.39 & 1.39 \\
\hline$\Sigma \mathrm{PAHt}$ & 2.02 & 2.02 & 2.03 & 2.02 & 2.03 & 2.04 & 2.03 & 2.07 & 2.06 \\
\hline$\Sigma \mathrm{CPAHs}$ & 0.82 & 0.82 & 0.82 & 0.81 & 0.81 & 0.82 & 0.82 & 0.82 & 0.82 \\
\hline$\%$ Organic carbon & 2.27 & 1.79 & 2.1235 & 1.9382 & 1.6294 & 1.8441 & 1.6176 & 1.8794 & 1.9912 \\
\hline $\mathrm{Fla} / \mathrm{Fla}+\mathrm{Pyr}$ & 0.50 & 0.50 & 0.5 & 0.5 & 0.5 & 0.5 & 0.5 & 0.5 & 0.5 \\
\hline $\mathrm{BaA} / \mathrm{BaA}+\mathrm{Chrys}$ & 0.48 & 0.48 & 0.4848 & 0.4848 & 0.4848 & 0.4848 & 0.4848 & 0.4848 & 0.4848 \\
\hline LMW/HMW & 0.32 & 0.33 & 0.3304 & 0.3246 & 0.3421 & 0.3217 & 0.3217 & 0.3304 & 0.3391 \\
\hline Naph/Phen & 1.08 & 1.00 & 1.0714 & 1.2308 & 1 & 1.2308 & 1.1538 & 1.3571 & 1.0667 \\
\hline Fla/Pyr & 1.00 & 1.00 & 1 & 1 & 1 & 1 & 1 & 1 & 1 \\
\hline IndcdP/IndcdP+BghiP & 0.47 & 0.47 & 0.4667 & 0.4667 & 0.4667 & 0.4667 & 0.4667 & 0.4667 & 0.4667 \\
\hline Total Index & 6.01 & 6.01 & 6.0076 & 6.0076 & 6.0076 & 6.0076 & 6.0076 & 6.0076 & 6.0076 \\
\hline $\begin{array}{l}\text { Ratio of } \Sigma \text { PAHs ( } 2-3 \\
\text { rings)/ } \Sigma \text { PAHs ( } 4-6 \text { rings) }\end{array}$ & 0.45 & 0.45 & 0.4604 & 0.4638 & 0.471 & 0.4676 & 0.4604 & 0.4892 & 0.482 \\
\hline
\end{tabular}

Table 2. Environmental Index of Polyaromatic Hydrocarbons (PAHs) in the Subsurface Soil Samples.

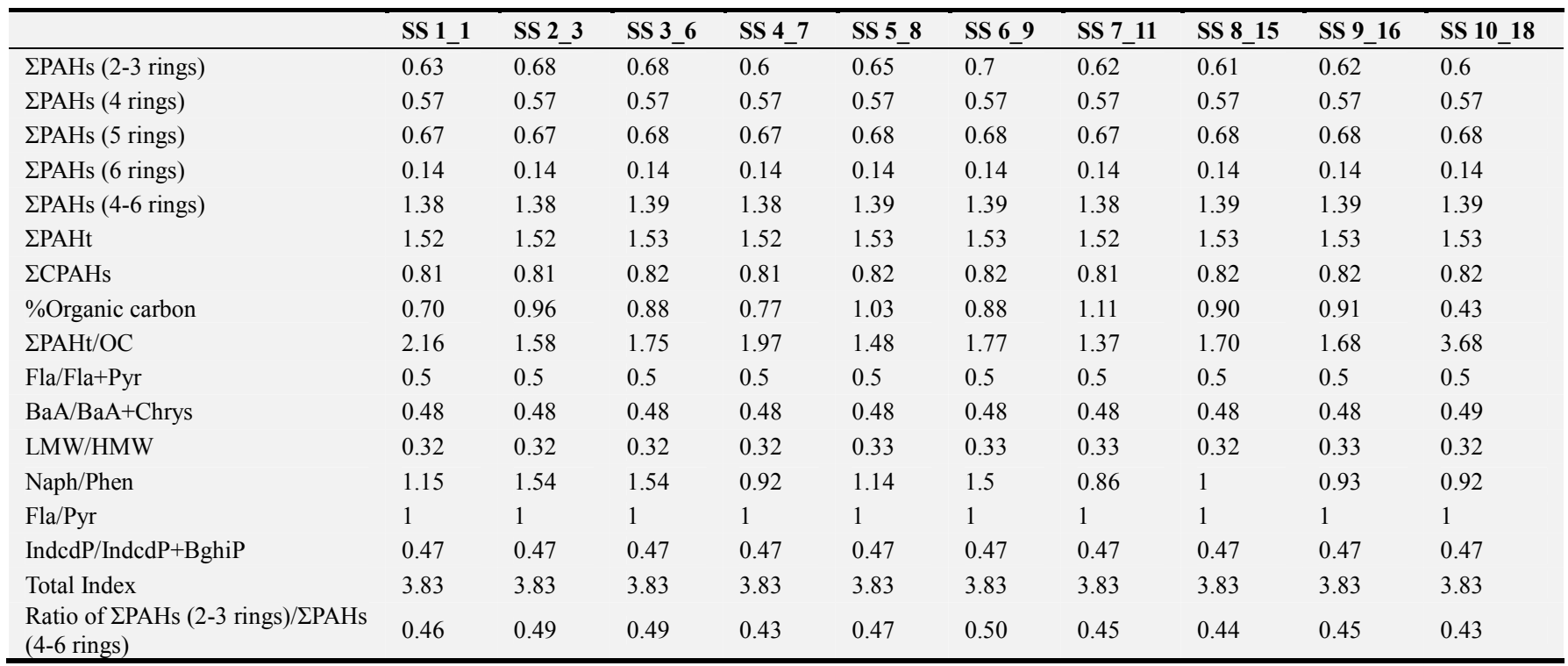


Table 2. Continued.

\begin{tabular}{|c|c|c|c|c|c|c|c|c|c|}
\hline & SS 11_20 & SS 12_23 & SS 13_24 & SS 14_27 & SS 15_30 & SS 16_31 & SS 17_33 & SS 18_35 & SS 19_37 \\
\hline$\Sigma$ PAHs (2-3 rings) & 0.61 & 0.64 & 2.17 & 2.08 & 1.95 & 2.1 & 2.25 & 2.33 & 2.21 \\
\hline$\Sigma$ PAHs (4 rings) & 0.57 & 0.57 & 0.57 & 0.57 & 0.57 & 0.57 & 0.59 & 0.58 & 0.57 \\
\hline$\Sigma$ PAHs (5 rings) & 0.68 & 0.68 & 0.68 & 0.68 & 0.69 & 0.68 & 0.69 & 0.68 & 0.68 \\
\hline$\Sigma$ PAHs (6 rings) & 0.14 & 0.14 & 0.14 & 0.14 & 0.14 & 0.14 & 0.14 & 0.14 & 0.14 \\
\hline$\Sigma$ PAHs (4-6 rings) & 1.39 & 1.39 & 1.39 & 1.39 & 1.4 & 1.39 & 1.42 & 1.4 & 1.39 \\
\hline$\Sigma$ PAHt & 1.53 & 1.53 & 1.53 & 1.53 & 1.54 & 1.53 & 1.56 & 1.54 & 1.53 \\
\hline ¿CPAHs & 0.82 & 0.82 & 0.82 & 0.82 & 0.83 & 0.82 & 0.83 & 0.82 & 0.82 \\
\hline$\%$ Organic carbon & 0.99 & 0.87 & 0.91 & 0.79 & 1.20 & 0.91 & 1.05 & 0.71 & 0.97 \\
\hline$\Sigma \mathrm{PAHt} / \mathrm{OC}$ & 1.55 & 1.75 & 1.69 & 1.94 & 1.28 & 1.67 & 1.49 & 2.16 & 1.58 \\
\hline $\mathrm{Fla} / \mathrm{Fla}+\mathrm{Pyr}$ & 0.5 & 0.5 & 0.5 & 0.5 & 0.5 & 0.5 & 0.54 & 0.48 & 0.5 \\
\hline $\mathrm{BaA} / \mathrm{BaA}+\mathrm{Chrys}$ & 0.48 & 0.48 & 0.48 & 0.48 & 0.48 & 0.48 & 0.48 & 0.48 & 0.48 \\
\hline LMW/HMW & 0.37 & 0.32 & 0.67 & 0.69 & 0.63 & 0.65 & 0.72 & 0.76 & 0.70 \\
\hline Naph/Phen & 1 & 1.08 & 0.38 & 0.35 & 0.31 & 0.39 & 0.32 & 0.34 & 0.35 \\
\hline Fla/Pyr & 1 & 1 & 1 & 1 & 1 & 1 & 1.17 & 0.92 & 1 \\
\hline Total Index & 3.83 & 3.83 & 3.83 & 3.83 & 3.83 & 3.83 & 3.92 & 3.78 & 3.83 \\
\hline $\begin{array}{l}\text { Ratio of } \Sigma \text { PAHs ( } 2-3 \\
\text { rings)/ } / \Sigma \text { PAHs ( } 4-6 \text { rings) }\end{array}$ & 0.44 & 0.46 & 1.56 & 1.50 & 1.39 & 1.51 & 1.58 & 1.66 & 1.59 \\
\hline
\end{tabular}

\section{Conclusion}

The regional concentration of PAHs in the study area did not show appreciable variation as most data obtained were almost constant for all the PAHs in all the soil samples analysed; this is especially true for surface soil samples. The distributions of PAHs in the study area are not of any public concern because their concentrations were lower than quoted contaminated averages. The diagnostics source apportionment indicates that the surface soil PAHs are derived principally from pyrogenic sources which atypically bush burning that was predominant in the study area; this was in contrast to the conclusion drawn by Olajire et al (2007) of both pyrogenic and petrogenic origin. The subsurface soil could either be pyrogenic for samples 1 to 12 or petrogenic for samples 13 to 19 . This demarcation is significant when considering the sample location within the study area; samples 1 to 12 were slightly outside the bitumen belt while samples 13 to 19 were clearly located on the belt. This may be a contaminated source from nearsurface bitumen deposits and a probable concern for crop production in the area.

\section{Acknowledgement}

The authors wish to acknowledge the funding provided by the Government of Nigeria through ETF Tertiary Education Fund obtained through The Federal University of technology, Akure, Ondo State and also the Commonwealth Scholarship of the Government of Canada through the exchange programme of Western University, London, Ontario. The assistance of Mr. Tim Stephen (Research Technologist) and other members of the Department of Civil and Environmental Engineering, Western University, Canada were highly appreciated. Special thanks to Prof. E. K Yanful for facilitating the exchange and allowing the use of his laboratory facilities.

\section{References}

[1] Zhang, W., Wei, C., Feng, C., Yu, Z., Ren, M., Yau, B., Peng, P. and Fu, J. (2011). Distribution and Health-risk of Polycyclic Aromatic Hydrocarbon in Soil at a Cooking Plant. J. Environ. Monit. 13, 3429-3436.

[2] Allison, T. A. New NIST Online Database: The NIST Polycyclic Aromatic Hydrocarbon Structure Index, 2014. http://www.nist.gov/mml/csd/nist-polycyclic-aromatichydrocarbon-structure-index.cfm.. Downloaded on 19th March, 2014.

[3] Mumtaz, M. M., George, I. D., Gold, K. W., Cibulas, W. and Derosa, C. T. (19960. ASTDR Evaluation of Health Effects of Chemicals. IV. Polycyclic Aromatic Hydrocarbons (PAHs); Understanding a Complex Problem. ASTDR Publication, 230p.

[4] Adamczewska, M., Siepak, J. and Gramowska, H. (2000). Studies of Levels of Polycyclic. Aromatic Hydrocarbons in Soils Subjected to Anthropopressure in the City of Poznan. Polish Journal of Environmental Studies, 9 (4), 305-321.

[5] Ramesh, A., Archibong, A. E., Hood, D. B., Guo, Z. and Loganathan, B. G. (2012). Global Environmental Distribution and Human Health Effects of Polycyclic Aromatic Hydrocarbon. In "Loganathan, B. G., Lam, P. K. S. Global Contamination Trends of Persistent Organic Chemicals". First Edition, CRC Press, Taylor and Francis Group, LLC: pp 97-126.

[6] Manzano, C., Hoh, E. and Simonich, M. S. L. (2012). Improved Separation of Complex Polycyclic Aromatic Hydrocarbon Mixtures Using Novel Column Combinations in GCxGC/ToF-MS. Environ. Sci. Technol., 46 (14), 7677-7684.

[7] Snezana, Z. K., Nikola, J. M., Mira, M. P., Zvonimir, J. S. and Jaroslava, V. S-G. (2005). Determination of Polycyclic Aromatic Hydrocarbons in Soil by Gas Chromatography-Mass Spectrometry, APTEFF, 36, 99-109

[8] Albers, P. H. (2002). Chapter 4-Petroleum and Individual Polycyclic Aromatic Hydrocarbons. In "Hoffman, D. J. (ed). Handbook of Ecotoxicology", Second Edition, CRC Press: Boca Raton, pp 1312. 
[9] Wang, G., Zhang, Q., Ma, P., Powden, J., Mielke, H. W., Gonzales, C. and Powell, E. (2008). Sources and Distribution of Polycyclic Aromatic Hydrocarbons in Urban Soils: Case Studies of Detroit and New Orleans. Soil and Sediment Contaminations, 17, 1-17.

[10] Stroomberg, G. J., Zappey, H., Steen, R. J., van Gestel, C. A., Ariese, F., Velthorst, N. H. and van Straaten, N. M. (2004). PAH Biotransformation in Terrestrial Invertebrates: A New Phase II Metabolites in Isopods and Springtails. Comp Biochem Physiol C Toxicol Pharmacol., 138 (2), 129-137.

[11] Vecera, Z., Bartosikova, A., Sklenska, J. and Mkuska, P. (2005). A large Volume Injection Procedure for GC-MS Determination of PAHs and PCBs. Chromatographia, 61 (3/4), 197-200.

[12] Khan, Z., Troquet, J. and Vachelard, C. (2005). Sample Preparation and Analytical Techniques for Determination of Polyaromatic Hydrocarbon in Soils. Int. J. Environ. Sci. Tech.; 2 (3), 275-286

[13] Lau, E. V., Gan, S. and Ng, H. K. (2010). Extraction Techniques for Polycyclic Aromatic Hydrocarbons in Soils. International Journal of Analytical Chemistry, 10, 1-9.

[14] Olajire, A. A. and Brack, W. (2005). Polycyclic Aromatic Hydrocarbons in Niger Delta Soil: Contamination Sources and Profiles. Int. J. Environ. Sci. Tech., 2 (4), 343-352

[15] Olajire, A. A., Altenburger, R., Kuster, E. and Brack, W. (2005). Chemical and Ecotoxicological Assessment of Polycyclic Aromatic Hydrocarbon-Contaminated Sediments of the Niger Delta, Southern, Nigeria. Science of the Total Environment, 340, 123-136.

[16] Okoro, D. and Ikolo, O. A. (2007). Spatial Variation and Distribution of Polycyclic Aromatic Hydrocarbons in Soil. Bull. Chem. Soc. Ethiop., 21 (3), 331-340.

[17] Olajire, A. A., Alade, A. O., Adeniyi, A. A. and Olabemiwo O. M. (2007). Distribution of Polycyclic Aromatic Hydrocarbon in Surface Soils and Water from the Vicinity of Agbabu Bitumen Field of South Western Nigeria. Journal of Environmental Science and Health, PartA: Toxic/Hazardous Substances and Environmental Engineering, 42, 1043-1049.

[18] Ana, G. R. E. E., Sridhar, M. K. C. and Emerole, G. O. A. (2009). A Comparative Assessment of Soil Pollution by polycyclic Aromatic Hydrocarbons in two Niger Delta Communities, Nigeria. African Journal of Pure and Applied Chemistry, 3 (3), 031-041

[19] Sojinu, O. S. S., Wang, J-Z., Sonibare, O. O. and Zeng, E. Y. (2010). Polycyclic Aromatic Hydrocarbon in Sediments and Soil from Oil Exploration Areas of the Niger Delta, Nigeria. Journal of Hazardous Materials, 174, 641-647.

[20] Charles, I. O. and Adaku, N. M. (2010). Polycyclic Aromatic Hydrocarbons (PAHs) and Benzene, Toluene, Ethyl benzene and Xylene (BTEX) Contamination in Soil in Automobile Workshop in Port-Harcourt Metropolis, River State, Nigeria. Journal of America Science, 6 (9), 242-246.

[21] Sojinu, O. S., Sonibare, O. O. and Zeng, E. Y. (2011). Concentrations of Polycyclic Aromatic Hydrocarbons in Soils of a Mangrove Forest Affected by Forest Fire. Toxicol. Environ. Chem., 93 (3), 450-461.

[22] Oyo-Ita, O. E. and Oyo-Ita, I. O. (2012). Distribution of Polycyclic Aromatic Hydrocarbons (PAHs) and Sterols in Termite
Nest, Soil and Sediment from Great Kwa River, SE Nigeria. Environ. Moni. Assess. DDT 10:1007/s/0661-012-2641-x.

[23] Wang, W., Meng, B., Lu, X., Liu, Y. and Tao, S. (2007). Extraction of Polycyclic Aromatic Hydrocarbon and Organchlorine Pesticides from Soils: A Comparison between Soxhlet Extraction, Microwave- Assisted Extraction and Accelerated Solvent Extraction Techniques. Analytica Chimica Acta, 602, 211-222.

[24] Wang, R., Liu, G., Chou, C-L., Liu, J. and Zhang, J. (2010). Environmental Assessment of PAHs in Soils Around the Anhui Coal District, China. Arch. Environ. Contain. Toxicol., $59,62-70$

[25] Belanchen K. T., Chaoui A., Budzinski H., Bellocq J. and Garrigues Ph. (1997). Distribution and Sources of Polycyclic Aromatic Hydrocarbons in some Mediterranean Coastal Sediments. Mar. Pollut. Bull., 34, 298-305.

[26] Yunker, M. B., Macdonald, R. W., Vingarzan, R., Mitchell, R. H., Goyette, D. and Sylvestre, S. (2002). PAHs in the fraser river basin: A Critical Appraisal of PAHs Ratios as Indicators of PAHs Source and Composition. Organic Geochemistry 33, 489-515.

[27] Ma, L. L., Chu, S. G., Wang, X. T., Cheng, H. X., Liu, X. F. and $\mathrm{Xu}, \mathrm{X}$. B. (2005). Polycyclic Aromatic Hydrocarbons in the Surface Soils from Outskirts of Beijing, China. Chemosphere, 58, 1355-1363.

[28] Liu, Y., Chen, L., Jianfu, Z., Huang, Q., Zhiliang, Z. and Hongwen, G. (2008). Distribution and Sources of Polycyclic Aromatic Hydrocarbons in Surface Sediments of Rivers and an Estuary in Shanghai, China. Environmental Pollution, 154, 298-305.

[29] Readman J. W., Fillmann G., Tolosa I., Bartocci J., Villeneuve J. P., Catinni C. and Mee, L. D. (2002). Petroleum and PAH contamination of the Black Sea. Mar. Pollut. Bull., 44, 48-62.

[30] Li, X., Ma, L., Liu, X., Fu, S., Cheng, H. and Xu, X. (2006). Polycyclic Aromatic Hydrocarbon in Urban Soil from Beijing, China. J. Environ. Sci., 18, 944-950.

[31] Ekpo, B. O., Oyo-Ita, O. E., Oros, B., H. and Simoneit, B. R. T. (2011). Distributions and Sources of Polycyclic Aromatic Hydrocarbons in Surface Sediments from the Cross River estuary, S. E. Niger Delta, Nigeria. Environmental Monitoring and Assessment. DOI: 10.1007/s10661-011-2019-5.

[32] Radke, M., Willsch, J. and Rapp, J. B. (1991). A Statistical Approach to the Interpretation of Aliphatic Hydrocarbons Distribution in Marine Sediments. Chemical Geology, 93, 163-177.

[33] Dahle, S., Savinov, V. M., Matishov, G. G., Evenset, A. and Naes, K. (2003). Polycyclic Aromatic Hydrocarbons (PAHs) in Bottom Sediments of the Kara Sea Shelf, Gulf of $\mathrm{Ob}$ and Yenisei Bay. Sci. Total Environ., 306, 57-71.

[34] Soclo, H. H., Garrigues, P. and Ewald, M. (2000). Origin of Polycyclic Aromatic Hydrocarbons (PAHs) in Coastal Marine Sediments: Case Studies in Cotonou (Benin) and Aquitaine (France) Areas. Mar. Pollut. Bull., 40, 387-396.

[35] Orecchio, S. (2010). Assessmenet of Polycyclic Aromatic Hydrocarbn (PAHs) in Soil of a Natural Reserve (Isola delle Femmine) (Italy) Located in Front of a Plant for the Production of Cement. Journal of Hazardous Materials, 173, 358-368. 